\section{JTET}

http://penerbit.uthm.edu.my/ojs/index.php/jtet ISSN 2229-8932 e-ISSN 2600-7932
Journal of Technical

Education and

Training

\title{
Thinking Style Pattern Among Design and Technology Teachers in Malaysia
}

\section{Shanty Saien ${ }^{1}$, Tee Tze Kiong ${ }^{2 *}$, Jailani Md Yunos ${ }^{3}$, Yee Mei Heong ${ }^{4}$, Mimi Mohaffyza Mohamad ${ }^{5}$, Widad Othman ${ }^{6}$, Mohamed Nor Azhari Azman ${ }^{7}$, Zaliza Hanapi ${ }^{8}$ \& Nurulwahida Azid ${ }^{9}$}

\author{
1, 2, 3, 4, 5 Faculty of Technical and Vocational Education, Universiti Tun Hussein Onn Malaysia, Johor, MALAYSIA \\ ${ }^{6}$ Faculty of Education and Linguistic, Open University Malaysia, Kuala Lumpur, MALAYSIA \\ ${ }^{7,8}$ Faculty of Technical and Vocational, Universiti Pendidikan Sultan Idris, Perak, MALAYSIA \\ ${ }^{9}$ School of Education and Modern Languages, Universiti Utara Malaysia, Kedah, MALAYSIA
}

DOI: https://doi.org/10.30880/jtet.2019.11.03.006

Received $15^{\text {th }}$ August 2018; Accepted $3^{\text {rd }}$ September 2019; Available online $30^{\text {th }}$ September 2019

\begin{abstract}
Critical and creative thinking skills are vital in new Malaysia curriculum starting 2011. These skills are advised to be integrated in all subjects in school. Hence, knowing the teachers thinking style can be an advantage as this can give the impression on how the students will be. This study was conducted to identify the tendency to which creative critical thinking style of Design and Technology (DT) teachers across Malaysia. A total of 367 teachers are involved and required to answer the instrument known as YPCreative-Critical Test which consist of 34 items. This instrument was develop using Google Form and been send out to the respondent through email, Facebook, WhatsApp, Telegram and Instagram application to ease the teachers to respond online. The data then analyzed using descriptive statistic and inferential statistics. The finding from this study showed that nearly half of the DT teachers having balance thinking style. Creative thinking style has $35.4 \%$ of the total while critical thinking style $19 \%$. None of our teachers has superior thinking style. The independent $\mathrm{t}$-test result shows there is no significant difference thinking styles among DT teachers in gender.
\end{abstract}

Keywords: Critical and creative thinking skills, design and technology, balance thinking style, superior thinking style

\section{Introduction}

The $21^{\text {st }}$ Century skills is the term used widely in education. It refers to a broad set of knowledge, work habit and skills that are believed by educators and employees to be very important in today's world (Mohd Kasran, 2016). As in Malaysia, due to these $21^{\text {st }}$ Century skills demand, the education system has been transformed to a new curriculum started 2011. This new curriculum focused on critical thinking that will be adapted in class. In line with that, Malaysia Education Blueprint 2015-2025 also expresses the importance of critical and creative thinking to produce first class human resource 
Thus, critical and creative thinking of teaching and learning been implemented in school. However, in order to get the best outcome of student having critical and creative thinking, the students' thinking style should be known first (Hashmi, Shahibuddin, \& Hazlinda, 2018). This is because the right teaching and learning strategy that match the student thinking styles can lead to better academic achievement. As creative and critical thinking is very crucial (Padget, 2012), teacher is expected to have this ability and thus teach the student appropriately. However, the expectation and the reality are not much to be known (Fan \& Zhang, 2014). As creative and critical thinking is one of the elements use in designing and inventing in Design and Technology Subject (DT), therefore, this study was conducted to identify thinking style among Design and Technology (DT) teachers in Malaysia.

\subsection{Thinking Style}

Thinking styles can be viewed from many perspectives (Alias \& Abd Hadi, 2010). Whether it is from the perspective of management, business or education, thinking styles will have their own treat and characteristics. From the perspective of management, Li \& Armstrong, (2015) explain four types of styles which are converger, diverger, assimilator and accommodator. While from a business perspectives, Chen, Chang, \& Lo (2015) tends to use convergent and divergent thinking only. From the perspectives of education in Malaysia, thinking style has been classified into two, which is creative thinking and critical thinking. Fig. 1 shows The Thinking Skills Model that has been used by teachers in Malaysia since 1994. It shows the creative and critical thinking that should be adapted in class during the teaching and learning process. The creative and critical thinking skills is needed in the next process, which is reasoning and therefore lead student to problem solving (Rahman et al., 2002).

However, the outcome of what been taught and learned will lie on the hand of the teachers (Hamimi \& Saat, 2013). The great teacher will not only teach their students but also show the appropriate role of being what they taught. It's been said, that thinking style is associated with learning style preference by student (Oordt, Hills, \& Toit, 2014). Thus, to teach creative and critical thinking skills to the student, teachers themselves should have the ability of being creative and critical. Fan \& Zhang (2014) also emphasize student thinking style depending on a way of teachers teaching. Hence, there is a wonder point on the teaching ability of Design and Technology (DT) teacher in Malaysia relating to their style of thinking.

Teachers' thinking style can be identified from many instruments offered by researchers that works on thinking field. "YANPIAW Creative-Critical Thinking Styles Test" or YCREATIVE-CRITICALS is one of the instruments that offered to assess thinking style. The general criteria for developing the items in this instrument are; it must show relevance to thinking theory, must related to creative and critical thinking behaviour in the real world, it basically, shows different aspect of thinking behaviour, the items are attractive to the respondents, the respondent can respond according to their experiences, it must produce data that can give meaningful score and the instruction of administration and time limit has to be specified (Chua, 2010). Nevertheless, the item in YCREATIVE-CRITICALS also developed based on the rationales that both creative and critical thinking style is able to be identified, represented by score and can be quantify. However, the validity and reliability has been increased by excluding the overlapping traits for creative and critical thinking style when developing these items.

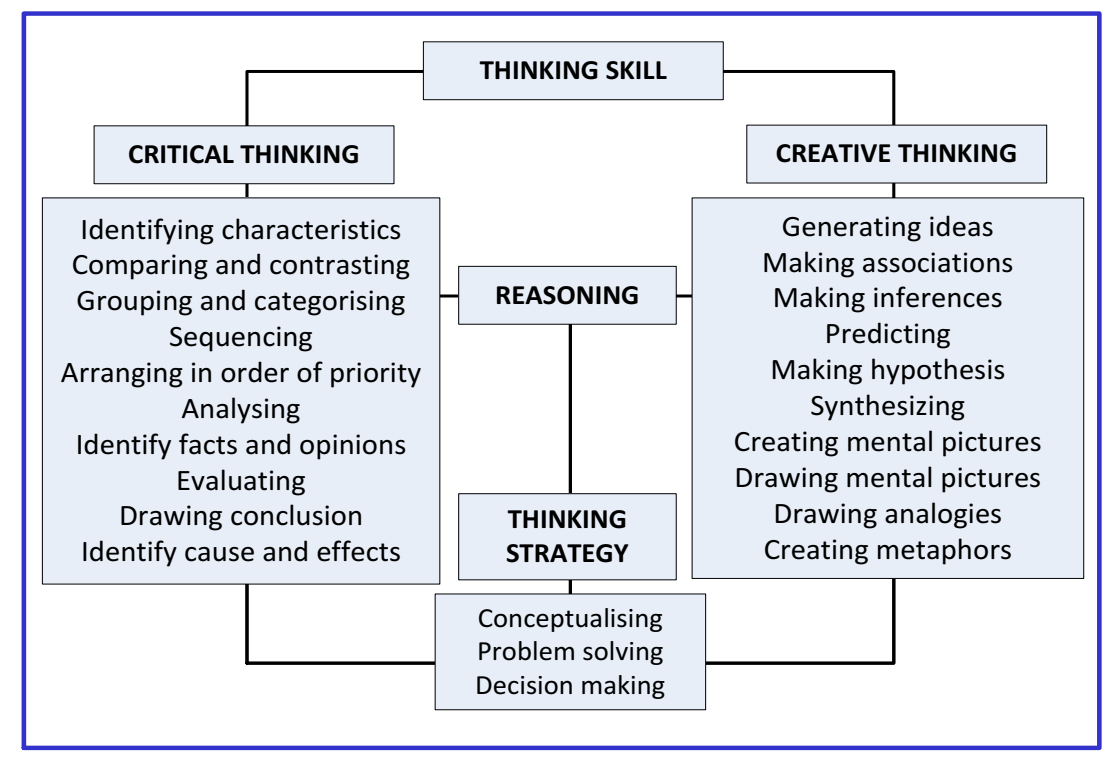

Fig. 1- The Thinking Skills Model (KPM, 2002)

The traits for creative thinking style are able to generate unique ideas, produce ideas that other could not think of, imaginative, able to view a problem from a variety of perspectives, interpret things other than normal ways, likely to 
disobey the rules, would not leap to conclusion easily, tend to daydreaming and emotional, good sense of humour, able to combine two elements into one, dynamic working of things, tend to show and recognize idea or objects in different visual way and appreciate the beauty of art.

While for critical thinking traits are tend to search the meaningful, clear, consistent, logical, accurate, precise, justify and relevant in everything. Other than that, traits like believe that there is only one way of being right, good in reasoning that leads to be able to define the problem, disbelief in magic and illusion, believe things cannot change in a short period of time, argumentative and has high judgment skills. The overlapping traits that been mention earlier were predicting, visualizing, anticipating and recognizing cause and effect.

\section{Methodology}

This research used quantitative approach. Survey design was used and data gathered using Google Form. This form then sent to the respondents through Facebook, WhatsApp, Telegram and Instagram application to help the respondents to respond online. A web-based self-report survey was used and this make the process of obtaining data is more reliable and valid (Osterman, 2015). The instrument YCREATIVE-CRITICALS has been developed by Professor Dr. Chua Yan Piaw based on creative thinking and critical thinking theories and research evidences (Chua, 2010).

The instrument YCREATIVE-CRITICALS consist of 32 multiple-choice items and each item of the test provides the respondent with choices which representing either creative thinking style or critical thinking style's function. Respondent are required to choose the answer that best reflected and describes their attitudes or behaviour.

After completing these questionnaires, the results will describe five different indications. Whether the respondent has Superior Creative Thinking Style, Creative Thinking Style, Balance Thinking Style, Superior Critical Thinking Style or Critical Thinking Style. The word superior resembles ones that has an extremely creative or critical features that shown in Figure 1. Figure 2, illustrated the YCREATIVE-CRITICAL Scoring Indicator. This scoring will indicate five different indicator which are Superior Critical Thinking Style, Critical Thinking Style, Balance thinking Style, Creative Thinking Style and Superior Creative Thinking Style. The score will be calculated by using the formula;

$$
\frac{\text { Total mark for } 32 \text { items }}{\text { Total answer chosen }}=\text { score indication }
$$

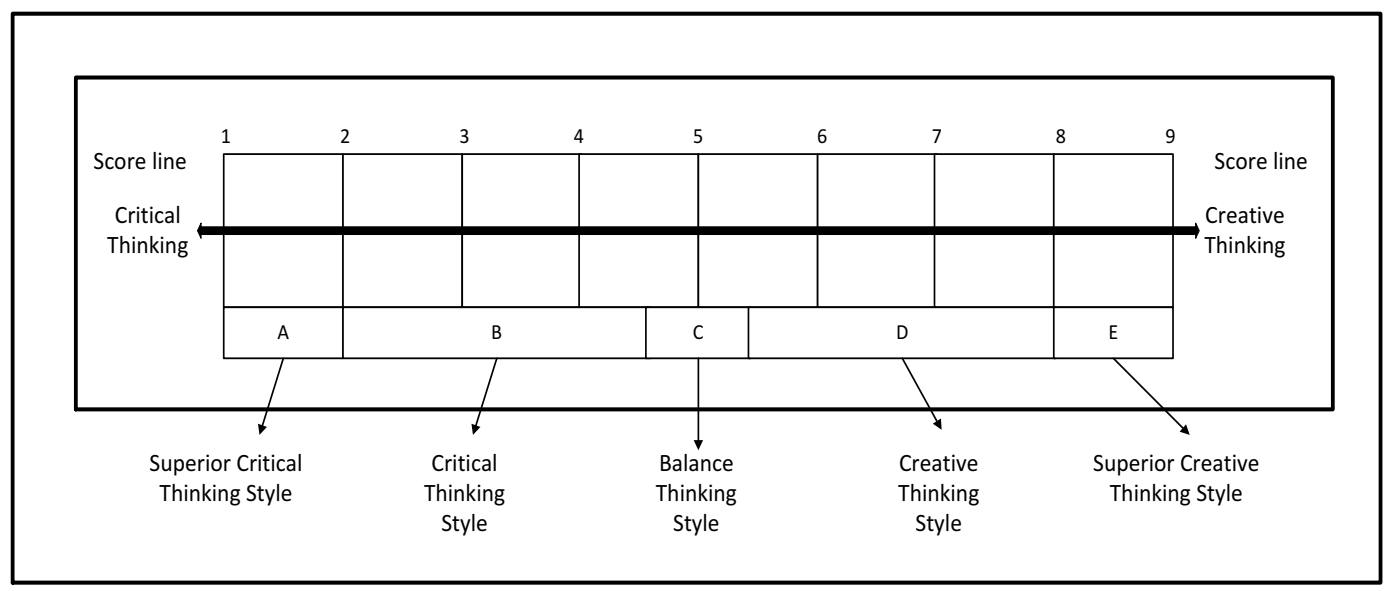

Fig. 2 - YCREATIVE-CRITICAL Scoring Indicator

Thus, this will give interval data. Scoring less than 1.99 will fall under Superior Critical Thinking Style, between 2.00 and 4.49 is Critical Thinking Style, between 4.50 and 5.49 is Balance Thinking Style, between 5.50 and 8.99 is Creative Thinking Style and scoring above 9.00 will falls under Superior Creative Thinking Style. The target population for this study was DT primary school teachers who had experience teaching DT subject. There are 7772 primary school in Malaysia and by normal practice, there will be one DT teacher in each school. By assuming the total number of respondent is 8000 , according to Krejcie Morgan's table, 367 respondents are appropriate (Krejcie \& Morgan, 1970). Table 1 illustrate the distribution of population and samples across Malaysia. The response rate for this study was $87.7 \%$. For web and online questionnaires 30\% response rate is acceptable (Aloun, 2012). Thus, 322 data were collected and imported to SPPS in order to conduct descriptive and inferential statistical analysis. 
Table 1 - The distribution of population and sample

\begin{tabular}{llcc}
\hline Zone & State & Population & Sample \\
\hline Zone 1 & Sabah & 1072 & 51 \\
& Sarawak & 1264 & 60 \\
& WP Labuan & 17 & 1 \\
Zone 2 & Johor & 905 & 43 \\
& Melaka & 237 & 11 \\
& Negeri Sembilan & 349 & 16 \\
Zone 3 & Perak & 852 & 40 \\
& Selangor & 659 & 31 \\
& WP Kuala Lumpur & 202 & 9 \\
Zone 4 & WP Putrajaya & 14 & 1 \\
& Kelantan & 418 & 20 \\
& Pahang & 539 & 25 \\
Zone 5 & Terengganu & 352 & 17 \\
& Kedah & 547 & 26 \\
& Pulau Pinang & 271 & 13 \\
& Perlis & 74 & 3 \\
\hline
\end{tabular}

\section{Result and Discussion}

Results shown in Fig. 3 (a), 45.3\% of DT teachers across Malaysia has Balance Thinking Styles. Followed by Creative Thinking Style (35.4\%) and least is Critical Thinking Style (19.3\%). There were no teachers having Superior Thinking Styles whether Critical nor Creative. There were good things about having Balance Thinking Style. This is because DT teachers with this style might able to solve problem by using certain whole brain skills. However, they still need to enrich their thinking skill by learning and thinking techniques such as mind mapping and mental arithmetic.

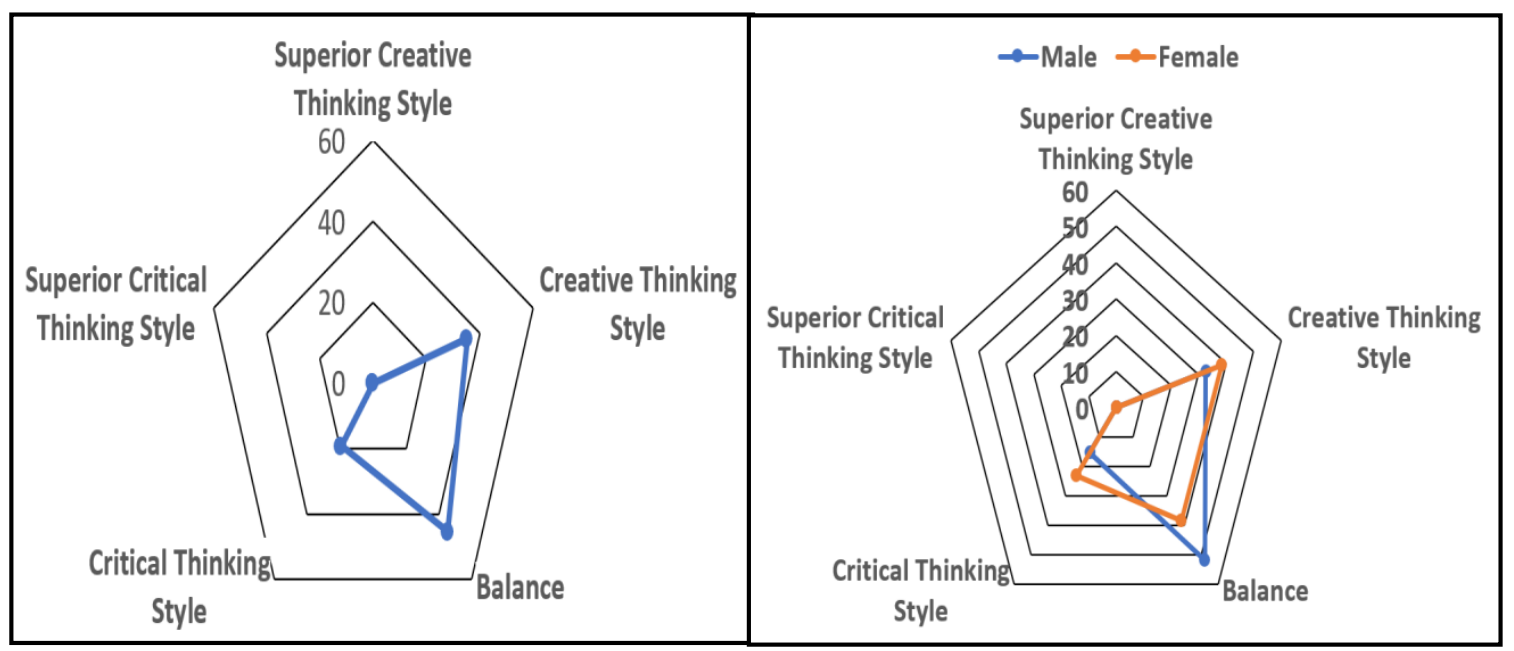

Fig. 3 - (a) Thinking Style pattern among DT Teachers in Malaysia; (b) Thinking Style pattern according to gender

This is not a surprise as creative grows with experience. Most of DT teachers has an experience of making project in class. Thus, they tend to be creative and innovative teachers. Teachers that falls under Critical Thinking Style may have less ability in producing unique ideas when it comes to project making. Thus, being the logic and rationale teacher in class will still make the class move on. The total of 322 respondents have almost alienated equally in terms of gender. 163 of total respondents are male and the rest of 159 are female. The result shown in Fig. 3 (b), illustrated that nearly half $(52.1 \%)$ of the male respondents has Balance Thinking Style. While for female, it has same distribution of Creative Thinking Style and Balance Thinking Style (38.4\% research). However, as the raw data collected were in the interval scale, therefore an independent t-test has been applied to determine the difference on thinking style based on gender. There was no significant difference on thinking style for male $(\mathrm{M}=5.26, \mathrm{SD}=0.92)$ and female $(\mathrm{M}=5.47, \mathrm{SD}=1.20)$ condition; $\mathrm{t}(320)=-1.71, \mathrm{p}=0.087$.

Even though the Creative Thinking Style has higher percentage compared to Critical Thinking Style but by looking at the distribution of point on the range (Fig. 4), it shows that the point for Creative Thinking Style which ranges between 2.00 to 4.49 has concentrated distribution. However, the range for point in Critical Thinking Style (5.50-8.99) has wide range of distribution. It can be spotted from Fig. 4 that few points are near the boundary line, meaning that few teachers 
are approaching the Superior Critical Thinking Style. These implies that group of creative teachers has an analogous level of creativity while the critical group has comparable level of critics.

On the other hand, an independent sample t-test was conducted to compare the thinking style among DT teachers of different gender. There was no significant difference in the score for male $(\mathrm{M}=5.26, \mathrm{SD}=.921)$ and female $(\mathrm{M}=5.47$, $\mathrm{SD}=1.21)$ teachers; $\mathrm{t}(320)=-1.717, \mathrm{p}=0.087$. This result shows that there is no significant difference in thinking style between DT teachers of different gender. Thus, teaching and learning session can be accomplished even though teachers differ in gender and thinking style. Although, this result resembles the other way around of what have been shown in Figure 3(a), but yet it demonstrates that by using interval data, it can represent the precise tabulation.

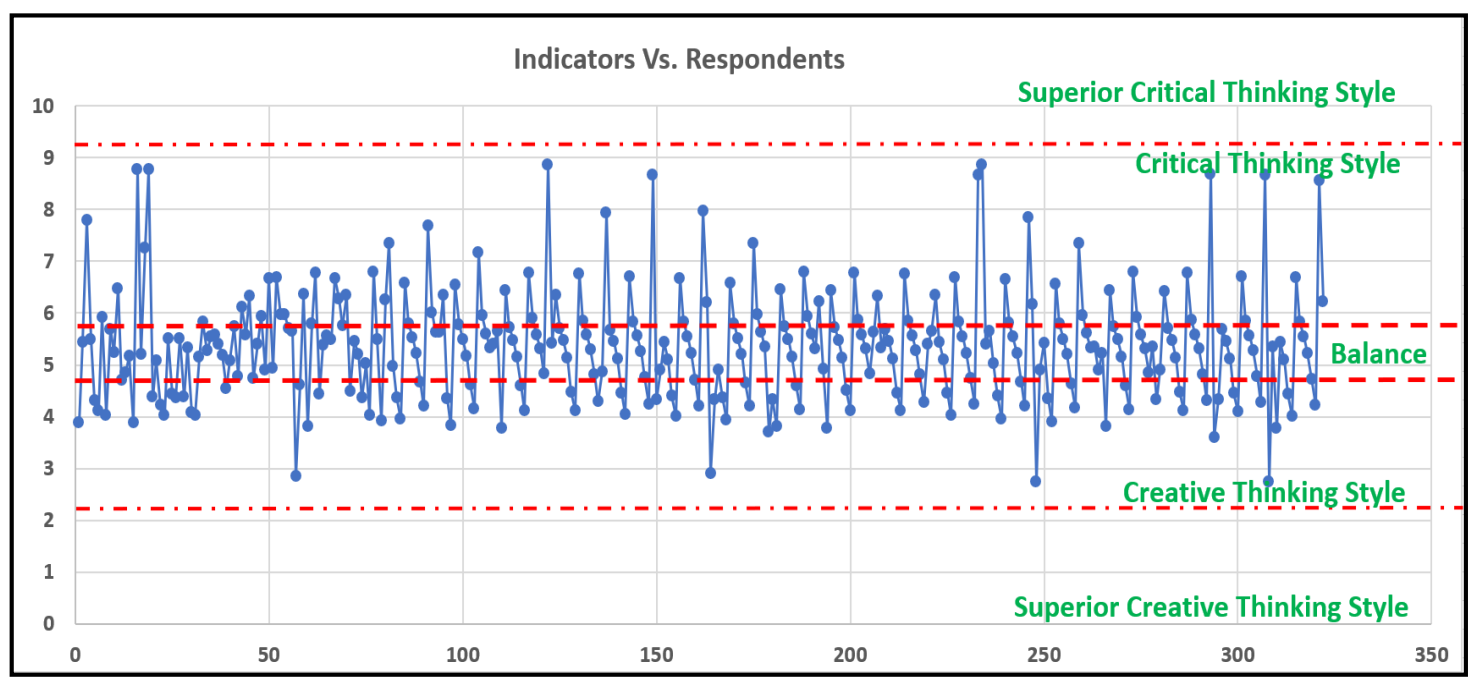

Fig. 4 - Thinking Style pattern among DT Teachers in Malaysia

\section{Conclusion}

Almost half of the DT teachers in Malaysia are found to have Balance Thinking Style and seems this trend only happens for male TD teachers. While for female TD teachers, they have almost equal number of Creative Thinking Style and Balance Thinking Style. TD Teachers who have Balance Thinking Style have both critical thinking and creative thinking skills that will lead them to solve problem effectively by using whole brain skills. Thus, for teachers having Creative Thinking Style, they need to improve their critical thinking skills so that they will have balance thinking style. Same goes to teacher that has Critical Thinking Style, in order to balance it, creative thinking skills shall be sharpened. The fact that no teacher get superior indicator should be a concern and focus for further research. This study provides some indication of the status of Malaysia DT teachers' thinking styles. It implies that there should be a shift in the teaching and learning strategy like for example by using module that accommodate creative and critical skills so that the students can be prepared with the demanded skills in 21 st century which is, as a good problem solver.

\section{Acknowledgement}

This project is financially supported by the Malaysia Ministry of Education under the VOT number V010 Graduate Teacher Programme Fund (PPG).

\section{References}

Alias, M., \& Abd Hadi, B. B. (2010). The Relationship Between Creative and Critical Thinking Styles and Academics Achievements Among Post Secondary Vocational Students. Seminar Kebangsaan Jawatankuasa Penyelarasan Pendidikan Guru 2010.

Aloun, N. A. (2012). Web-Based Internet Mobile Application to Manage Organization. Master Thesis. UUM. Retrieved from http://etd.uum.edu.my/3297/

Chen, M. H., Chang, Y. Y., \& Lo, Y. H. (2015). Creativity Cognitive Style, Conflict, and Career Success for Creative Entrepreneurs. Journal of Business Research, 68(4), 906-910. https://doi.org/10.1016/j.jbusres.2014.11.050

Chua, Y. P. (2004). Creative and Critical Thinking Styles. Serdang, Selangor: Universiti Putra Malaysia Press.

Chua, Y. P. (2010). Building a Test to Assess Creative and Critical Thinking Simultaneously. Procedia - Social and Behavioral Sciences, 2(2), 551-559. https://doi.org/10.1016/j.sbspro.2010.03.062

Fan, J., \& Zhang, L. (2014). The role of learning environments in thinking styles. Education Psychology, 34(2), 252- 
268.

H.A.Rahman, A. H., Mat Desa, D. F., Sirin, R., Sinappan, M., Mat Rodzi, M. D., Mohd Som, S., \& Yazid, Z. (2002). Kemahiran Berfikir Dalam Pengajaran dan Pembelajaran. (KPM, Ed.), Pusat Perkembangan Kurikulum, Kementerian Pendidikan Malaysia (2001st ed.). Kuala Lumpur: Pusat Perkembangan Kurikulum.

Hamimi, K. A., \& Saat, I. (2013). Kemahiran Pelestarian Pemikiran Dalam Pendidikan Sejarah. In Seminar Pendidikan Sejarah dan Geografi (Vol. 2013, pp. 29-30). UMS.

Hashmi, A., Shahibuddin, I., \& Hazlinda, H. (2018). A Role of Thinking Styles for Innovation, A Conceptual Framework with a Critical review of Literature. Asian Journal of Multidisciplinary Studies, 6(May), 68-75.

Krejcie, R. V, \& Morgan, D. W. (1970). ACTIVITIES. Educatonal and Psychological Measurement, 30, 607-610.

Li, M., \& Armstrong, S. J. (2015). The Relationship Between Kolb's Experiential Learning Styles and Big Five Personality Traits in International Managers. Personality and Individual Differences, 86, $422-426$. https://doi.org/10.1016/j.paid.2015.07.001

Mohd Kasran, M. H. (2016). Prosiding Seminar Penyelidikan Tindakan Pendidik Guru 2016. In M. H. Mohd Kasran (Ed.), 1 Pensyarah 1 Penyelidikan (p. 431). Institut Pendidikan Guru Kampus Sultan Mizan.

Oordt, M. van, Hills, T., \& Toit, P. du. (2014). Two teachers are better than one: collaborative teaching as an approach to promote whole brain learning Mr. ML van Oordt, Miss T Hills, Dr PH du Toit. Meditari Accountancy Research, 22(2), $165-185$.

Osterman, M. D. (2015). Exploring Relationships Between Thinking Style and Sex, Age, Academic Major, Occupation and Levels of Arts Engagement Among Professionals Working in Museums. FIU Electronic Theses and Dissertations. FIU Electronic Theses and Dissertations University, Florida International University. Retrieved from http://digitalcommons.fiu.edu/etd/2277

Padget, S. (2012). Creativity and Critical Thinking for teachers in training. In Creativity and Critical Thinking (Vol. 3, pp. 1-65). Abingdon, United Kingdom: Routledge. https://doi.org/0415692822 